\title{
Lipid Stability of Soybeans in Grains and Soybeans Processed as Tofu
}

\author{
J. M. A. Damásio ${ }^{1}$, L. A. Requião ${ }^{1}$, D. A. Santana ${ }^{1}$ M. V. Silva ${ }^{1}$, N. E. de $\operatorname{Souza}^{2}$, F. A. G. Coró ${ }^{2}$ \\ \& J. I. Simionato ${ }^{1,2}$ \\ ${ }^{1}$ Department of Basic and Instrumental Studies, Universidade Estadual do Sudoeste da Bahia, Praça Primavera, \\ Itapetinga, BA, Brazil \\ ${ }^{2}$ Food Technology Department, Universidade Tecnológica Federal do Paraná, Rua dos Pioneiros, Londrina, PR, \\ Brazil \\ Correspondence: Julliana I. Simionato, Department of Basic and Instrumental Studies, Universidade Estadual do \\ Sudoeste da Bahia, Praça Primavera, 40, Itapetinga, BA, 45700-000, Brazil. E-mail: jusimionato@gmail.com
}

Received: July 11, 2013 Accepted: August 16, 2013 Online Published: October 15, 2013

doi:10.5539/jas.v5n11p67 URL: http://dx.doi.org/10.5539/jas.v5n11p67

\begin{abstract}
Soybeans (Glycine $\max$ (L.) Merrill) contain bioactive substances. They are a functional, important food associated with reduced risks of chronic and degenerative diseases. This study assesses lipid stability and antioxidant in soy grains and processed soy tofu. The two soybean brands differed in antioxidant activity and total phenolic compounds, which ranged from $188.4 \mathrm{mg}$ EAG.100g ${ }^{-1}$ and 3.17 to $1.56 \mu \mathrm{mol}$ of ferrous sulfate $\mathrm{g}^{-1}$. Both tofu samples only showed differences in total phenolic compounds, which ranged from 9.6 to $18.3 \mathrm{mg}$ EAG. $100 \mathrm{~g}^{-1}$. Analysis of DPPH free radicals has not shown significant differences $(\mathrm{P}<0.05)$ amongst analyzed soybean in grain and tofu brands; yet, we could identify antioxidant activities with an inhibition level above $50 \%$. There was no significant difference among total lipid contents of the tested brands. Polyunsaturated and monounsaturated fatty acids found to be denser in soy and tofu samples were: linoleic, linolenic and oleic acid. The n-6/n-3 ratio values were satisfactory for soy and tofu. Thus, both soybean and tofu display significant antioxidant effects and are sources of polyunsaturated fatty acids.
\end{abstract}

Keywords: natural antioxidants, DPPH, FRAP, phenolic, fatty acids, Glycine $\max$ (L.) Merril

\section{Introduction}

Soybeans ([Glycine max (L.) Merrill] are widely produced in Brazil (Neves et al., 2013; Loss et al., 2012). The last years have seen a rise in their consumption due to their chemical and nutritional characteristics. They are a source of two essential fatty acids - linoleic and $\alpha$-linolenic — and plentiful protein. Health benefits are associated with the presence of phenolic compounds such as isoflavonoids. Such substances are important antioxidants that prevent noncommunicable chronic-degenerative diseases such as cancer (Wang et al., 2006).

The processing of food may alter the nutrients it contains (Tsai et al., 1981). Soybean grains often must soak in water to soften. With a proper heat treatment, this makes proteins more digestible while safeguarding the beans' nutritional value (Rockland \& Radke, 1981; Escueta et al., 1986; Wang \& Murphy, 1996; Bayran et al., 2004).

Despite its nutritional qualities, tofu is still little demanded in the Brazilian market. Likewise, only a few publications address its physicochemical characteristics, especially the quality and quantity of fatty acids that compose its lipid fraction (Axerold et al., 1981; Davies \& Nielsen, 1986; Rackis et al., 1979).

Many have investigated the relationship between soy consumption and human health on the basis of soy's nutritional characteristics. Breast, prostate, and colon cancer cases have decreased in Asian populations, wherein the estimated per capita intake of soybean is 20-50 times higher than that of Western populations (Crouse et al., 1999).

This study aimed to explore the chemical transformations that occur as soybean becomes tofu, including the evaluation of phenolic content, antioxidant activity (AA), and lipid composition of soybean before and after processing. 


\section{Materials and Method}

\subsection{Obtaining the Raw Material}

Were analyzed samples from two brands (A and B) of different soybean grains [Glycine max (L.) Merrill] marketed in most of the Brazilian territory and intended for in natural consumption.

\subsection{Obtaining the Tofu}

First, we obtained the water-soluble extract of soybean. Figure 1 illustrates the flowchart for obtaining respective tofus (A and B) from the acquired soybean samples.

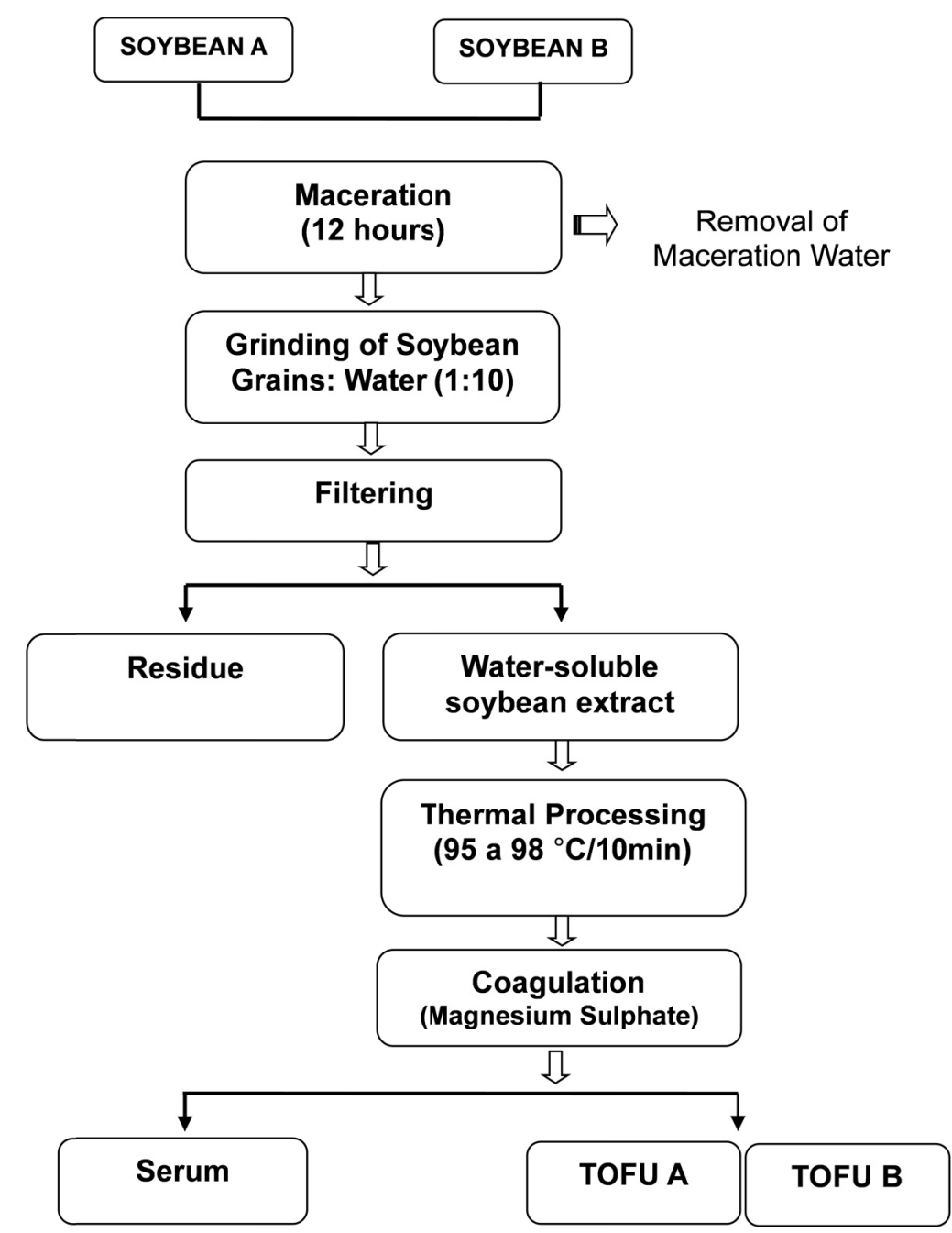

Figure 1. Flow chart illustrating the processing of tofu

\subsection{Fatty Acid Composition}

Were extracted the lipid fraction of the soy and its derivative in duplicate, in line with the methodology Bligh \& Dyer proposed (1959).

We used transesterification on extracted lipids, in line with methodology Bannon et al. proposed (1982), following the adaptations Simionato et al. suggested (2010). The fatty acids were analyzed with a Thermo Finnigan Trace GC Ultra gas chromatograph, equipped with a flame ionization detector (FID) and a fused silica capillary column BPX-70 (120 m, $0.25 \mathrm{~mm}$ d.i.). After checking the best resolution conditions, we set the injector at $250{ }^{\circ} \mathrm{C}$ and the detector at $280^{\circ} \mathrm{C}$. The column temperature was $140{ }^{\circ} \mathrm{C}$ for $10 \mathrm{~min}$, followed by a first ramp of $15{ }^{\circ} \mathrm{C} \mathrm{min}{ }^{-1}$ up to $200{ }^{\circ} \mathrm{C}$ for $1 \mathrm{~min}$. The second ramp was $10^{\circ} \mathrm{C} \mathrm{min}^{-1}$ up to $230{ }^{\circ} \mathrm{C}$ for 1 minute. The third ramp was $0.4{ }^{\circ} \mathrm{C} \mathrm{min}{ }^{-1}$ up to $233{ }^{\circ} \mathrm{C}$ for $3 \mathrm{~min}$. The fourth ramp was $0.5^{\circ} \mathrm{C} \mathrm{min}^{-1}$ up to $238^{\circ} \mathrm{C}$ for 2 minutes. The total 
analysis time was $41.50 \mathrm{~min}$. The gas flow rates were $30 \mathrm{~mL} \mathrm{~min}^{-1}$ for hydrogen, $30 \mathrm{~mL} \mathrm{~min}^{-1}$ for nitrogen and 250 $\mathrm{mL} \min ^{-1}$ for synthetic air.

Injections $(1.2 \mu \mathrm{L})$ were performed and the peak areas of methyl esters of fatty acids were determined by the software ChromQuest 4.1 (Thermo Electron, Italy).

The identification of fatty acids (FA) was carried out after verification of equivalent chain length of peaks and comparison of the retention times of samples with a pattern containing a mixture of fatty acid methyl esters (Sigma 189-19, USA), as described By Simionato et al. (2008). The quantification of fatty acids in g per $100 \mathrm{~g}$ of total lipids was performed by normalization of the peak areas of fatty acid methyl esters.

\subsection{Analysis of Antioxidants}

\subsubsection{Extraction}

Were obtained extracts of soybean and tofu as proposed by Hung et al. (2009), in triplicate by homogenizing about $1 \mathrm{~g}$ of soybean and tofu samples in $20 \mathrm{~mL}$ of methanol/water in a $4: 1$ ratio. We stirred for 20 minutes at room temperature, then filtered the extracts, centrifuged the suspension, and collected the supernatant. We stored the extracts in amber glass bottles at $-12{ }^{\circ} \mathrm{C}$ until the time of probable use.

\subsubsection{Determination of Total Phenolic Contents}

The spectrophotometric method determined the total phenolic contents of the methanol extracts, using the Folin-Ciocalteu reagent mix (Swain \& Hillis, 1959; Wettasingle \& Shahidi, 1999) and the standard curve of gallic acid (GAE). We expressed the results as mg of total phenolic contents in GAE per $100 \mathrm{~g}$ of sample. We mixed a $0.350 \mathrm{~mL}$ aliquot of the extract with $0.250 \mathrm{~mL}$ of Folin-Ciocalteu reagent and $0.5 \mathrm{~mL}$ of $20 \%$ sodium carbonate in amber tubes, thus adjusting the volume to $5 \mathrm{~mL}$ with distilled water. After the mix settled for 25 minutes, we read the absorbance at $773 \mathrm{~nm}$ to measure the total phenolic contents.

\subsubsection{Determination of Antioxidant Activity - $\mathrm{DPPH}^{\circ}$}

We measured antioxidant activity by reducing free radical levels of DPPH, as described by Brand-Williams et al. (1995) with some modifications (Sánchez-Moreno et al., 1998). Methanol extract aliquots of soybean and tofu at different concentrations $\left(4.5,7.5\right.$ and $10.0 \mathrm{mg} \mathrm{mL}^{-1}$ ) were added to $200 \mu \mathrm{L}$ of methanol solution of DPPH $60 \mu \mathrm{M}$. After stirring, the tubes stood in the dark for 30 minutes. After the reaction time elapsed, we obtained the absorbance of samples at $517 \mathrm{~nm}$, using methanol as the blank. We measured AA in two ways: via inhibitory concentration $\left(\mathrm{IC}_{50}\right)$, the amount of antioxidant necessary to halve the initial concentration of $\mathrm{DPPH}^{\circ}$, and via the oxidation inhibition percentage of the radical calculated from Equation 1:

$$
\% \text { Inibição DPHH• }=\frac{(\text { AbsDPPH } \bullet-A b s \text { amostra })}{A b s D P P H} \times 100
$$

\subsubsection{Determination of Iron Reducing Power (FRAP)}

Were assessed the extracts' reducing power (FRAP) according to Benzie \& Strain (1996), with some modifications. We obtained FRAP reagent from the combination of $2.5 \mathrm{~mL}$ of a $10 \mathrm{mM}$ TPTZ solution in $\mathrm{HCl} 40$ $\mathrm{mM}, 2.5 \mathrm{~mL}$ of ferric chloride and $20 \mathrm{mM}$ and $25 \mathrm{~mL}$ of $0.3 \mathrm{mM}$ acetate buffer (pH 3.6), used immediately after preparation. To evaluate antioxidant capacity, we transferred $350 \mu \mathrm{L}$ of a methanol extract aliquot to amber test tubes containing $270 \mu \mathrm{L}$ of distilled water and $2.7 \mathrm{~mL}$ of previously prepared FRAP reagent. After a shaker tube homogenized the samples, they incubated at $37{ }^{\circ} \mathrm{C}$ for 30 minutes. Then we made a reading at $595 \mathrm{~nm}$. Using solutions with different concentrations of ferrous sulfate, we constructed a calibration curve. Accordingly, we expressed the results as $\mu \mathrm{mol}$ of ferrous sulfate/g of the sample. Analyses were done in triplicate.

\subsection{Statistical Analyses}

The results were expressed as mean \pm standard deviation (SD). We compared means with analysis of variance (ANOVA) and Tukey's test $(\mathrm{p}<0.05)$ using Statistical Software $7.0(2005)$.

\section{Results and Discussion}

\subsection{Fatty Acids Composition}

Percentage of lipids in the soybean samples was 3.6\%, in line with the nutritional table labeled on the packaging. Tofu samples showed an average fat content of 5.5\%, below the values found by Benassi et al. (2011), which ranged between $23 \%$ and $30 \%$. There were no significant differences between the total lipid contents of both soybean and tofu brands evaluated. 
Were identified a total of 15 fatty acids in the tofu and soybean samples have been identified (Table 1). Both soybean and tofu have higher levels of polyunsaturated fatty acids (PUFA), ranging from $56.57 \%$ to $60.37 \%$ of total fatty acids, followed by monounsaturated (AGM) (23.62-25.04\%) and saturated fatty acids (AGP) $(15.77-17.95 \%)$.

Table 1. Fatty acid composition (\%) of soybean in grains and tofu.

\begin{tabular}{|c|c|c|c|c|}
\hline Fatty acids & Soybean A & Tofu A & Soybean B & Tofu B \\
\hline 14:0 & $0.088^{\text {ns }}$ & $0,080^{\mathrm{a}}$ & $0,122^{\mathrm{ns}}$ & $0,109^{\mathrm{ns}}$ \\
\hline $16: 0$ & $10,994^{\mathrm{ns}}$ & $10,737^{\mathrm{a}}$ & $12,525^{\mathrm{ns}}$ & $12,257^{\text {ns }}$ \\
\hline $16: 1 \mathrm{n}-9$ & $0,095^{\mathrm{ns}}$ & $0,087^{\mathrm{a}}$ & $0,117^{\mathrm{ns}}$ & $0,108^{\mathrm{ns}}$ \\
\hline $17: 0$ & $0,101^{\mathrm{ns}}$ & $0,110^{\mathrm{a}}$ & $0,108^{\mathrm{ns}}$ & $0,097^{\mathrm{ns}}$ \\
\hline $17: 1 \mathrm{n}-7$ & $0,052^{\text {ns }}$ & $0,058^{\mathrm{a}}$ & $0,053^{\mathrm{ns}}$ & $0,058^{\mathrm{ns}}$ \\
\hline 18:0 & $3,976^{\text {ns }}$ & $4,032^{\mathrm{a}}$ & $3,969^{\mathrm{ns}}$ & $3,962^{\mathrm{ns}}$ \\
\hline 18:1n-9 & $21,431^{\mathrm{ns}}$ & $21,739^{\mathrm{a}}$ & $21,387^{\mathrm{ns}}$ & $22,651^{\mathrm{ns}}$ \\
\hline $18: 1 \mathrm{n}-7$ & $1,945^{\mathrm{ns}}$ & $1,890^{\mathrm{a}}$ & $2,016^{\mathrm{ns}}$ & $2,079^{\mathrm{ns}}$ \\
\hline $18: 2 n-6$ & $51,346^{\mathrm{ns}}$ & $51,588^{\mathrm{a}}$ & $51,450^{\mathrm{ns}}$ & $51,692^{\text {ns }}$ \\
\hline $18: 3 n-6$ & $0,081^{\mathrm{ns}}$ & $0,063^{\mathrm{a}}$ & $0,097^{\mathrm{ns}}$ & $0,057^{\mathrm{ns}}$ \\
\hline $18: 3 n-3$ & $8,945^{\mathrm{ns}}$ & $8,674^{\mathrm{a}}$ & $6,763^{\mathrm{b}}$ & $5,818^{\mathrm{a}}$ \\
\hline 20:0 & $0,282^{\mathrm{ns}}$ & $0,320^{\mathrm{a}}$ & $0,349^{\mathrm{ns}}$ & $0,343^{\text {ns }}$ \\
\hline $20: 1$ & $0,093^{\mathrm{ns}}$ & $0,125^{\mathrm{a}}$ & $0,167^{\mathrm{ns}}$ & $0,154^{\mathrm{ns}}$ \\
\hline $22: 0$ & $0,472^{\mathrm{ns}}$ & $0,423^{\mathrm{a}}$ & $0,705^{\mathrm{a}}$ & $0,422^{b}$ \\
\hline $24: 0$ & $0,090^{\mathrm{ns}}$ & $0,066^{\mathrm{a}}$ & $0,165^{\text {ns }}$ & $0,077^{\text {ns }}$ \\
\hline SFA & $16.01^{\mathrm{ns}}$ & $15.77^{\mathrm{a}}$ & $17.95^{\mathrm{ns}}$ & $17.27^{\mathrm{ns}}$ \\
\hline MUFA & $60.37^{\mathrm{a}}$ & $60.33^{\text {ns }}$ & $58.31^{\mathrm{ns}}$ & $56.57^{\mathrm{ns}}$ \\
\hline PUFA & $23.62^{\mathrm{ns}}$ & $23.90^{\mathrm{ns}}$ & $23.74^{\mathrm{ns}}$ & $25.04^{\mathrm{ns}}$ \\
\hline$n-6$ & $51.43^{\mathrm{ns}}$ & $51.65^{\mathrm{ns}}$ & $51.55^{\mathrm{ns}}$ & $50.75^{\text {ns }}$ \\
\hline$n-3$ & $8.95^{\mathrm{ns}}$ & $8.67^{\mathrm{ns}}$ & $6.67^{\mathrm{ns}}$ & $5.82^{\mathrm{ns}}$ \\
\hline PUFA/SFA & $3.77^{\mathrm{ns}}$ & $3.83^{\mathrm{ns}}$ & $3.25^{\mathrm{ns}}$ & $3.28^{\mathrm{ns}}$ \\
\hline$n-6 / n-3$ & $5.75^{\mathrm{b}}$ & $5.95^{\mathrm{a}}$ & $7.62^{\mathrm{b}}$ & $8.72^{\mathrm{a}}$ \\
\hline
\end{tabular}

${ }^{\mathrm{a}, \mathrm{b}}$ Means followed by different letters differ statistically by the Tukey's test at $5 \%$ significance. SFA $=$ Total Saturated Fatty Acids; PUFA = Total Polyunsaturated Fatty Acids; MUFA $=$ Total monounsaturated fatty acids nsThere is no significant difference at $5 \%$ probability by $\mathrm{F}$ test.

The high degree of unsaturation previously addressed was due to the predominance of linoleic (51.34-51.69\%) and oleic acids (21.38-22.65\%), the former being an essential fatty acid.

The amounts of fatty acids in tofu resembled those in the raw material, indicating that processing does not promote important qualitative or quantitative changes $(p<0.05)$ in this class of compounds. Nevertheless, soybean and tofu samples of brand A have more omega- 3 and total polyunsaturated fatty acids than those of brand B.

The major polyunsaturated fatty acids found in soybeans and tofu samples were linoleic acid, 18:2n-6 (51.34-51.69\%) and $\alpha$-linolenic acid, 18:3n-3 (5.81-8.94\%).

For A and B respectively, n-6:n-3 ratios were 5.75 and 7.62 for soybean samples, whereas this ratios for tofu were 5.95 and 8.72. The linoleic and $\alpha$-linolenic fatty acid values in both tofu and brand A soybeans were near the optimum values for a human diet, as recommended by the Department of Agriculture of the United States (FAO, 2007), suggesting that this should lie between 5 and 10 . 
Also known as omega-9, oleic acid had the second highest concentration with no significant differences between soybean samples or derivatives. This monounsaturated acid is hyperlipidemic: it reduces cholesterol and low density lipoprotein (LDL) responsible for the formation of atheromas (Mcnamara, 1990).

Saturated fatty acids were in the samples, but in small quantities. The fatty acid profile suggests elevated palmitic (10.73-12.52\%) and stearic saturated fatty acid values (3.96-3.97\%). The United Kingdom Ministry of Health recommends the PUFA/SFA ratio of the lipid profile be above 0.4 to prevent diseases associated with saturated fat intake (Wood et al., 2003). The studied ratio is in line with this and can be used in low-cholesterol diets. All fatty acid values are in line with the reference table RDC No. 482 of 23/09/1999, the National Health Surveillance Agency (ANVISA).

For A and B respectively, n-6:n-3 ratios were 5.75 and 7.62 for soybean samples, whereas this ratios for tofu were 5.95 and 8.72. The linoleic and $\alpha$-linolenic fatty acid values in both tofu and brand A soybeans were near the optimum values for a human diet, as recommended by the Department of Agriculture of the United States (FAO, 2007), suggesting that this should lie between 5 and 10 .

Also known as omega-9, oleic acid had the second highest concentration with no significant differences between soybean samples or derivatives. This monounsaturated acid is hyperlipidemic: it reduces cholesterol and low density lipoprotein (LDL) responsible for the formation of atheromas (Mcnamara, 1990).

Saturated fatty acids were in the samples, but in small quantities. The fatty acid profile suggests elevated palmitic (10.73-12.52\%) and stearic saturated fatty acid values (3.96-3.97\%). The United Kingdom Ministry of Health recommends the PUFA/SFA ratio of the lipid profile be above 0.4 to prevent diseases associated with saturated fat intake (Wood et al., 2003). The studied ratio is in line with this and can be used in low-cholesterol diets.

All fatty acid values are in line with the reference table RDC No. 482 of 23/09/1999, the National Health Surveillance Agency (ANVISA).

\subsection{Determination of Total Phenolic Content and Antioxidant Capacity}

Table 2 shows the results of FRAP analysis of total phenolics and antioxidant activity.

The two brands of soybeans differed in FRAP antioxidant activity and total phenolic content. Tofu samples differed in total phenolic content, with 9.6 and $18.3 \mathrm{mg} \mathrm{GAE} 100 \mathrm{~g}^{-1}$. These differences may spring from plant genotype, environmental variations, sampling periods, or other factors (Shan et al., 2005).

Table 2. Antioxidant activity and total phenolic content in soybeans and tofu

\begin{tabular}{lll}
\hline PRODUCT/BRAND & $\begin{array}{l}\text { TOTAL PHENOLIC } \\
\text { CONTENTS } \\
\left(\mathrm{mg} \mathrm{GAE} .100 \mathrm{~g}^{-1}\right)^{*}\end{array}$ & $\begin{array}{l}\text { FRAP } \\
(\mu \mathrm{mol} \text { of Ferrous Sulphate. }\end{array}$ \\
\hline Soybean A in grains & $188,5^{\mathrm{a}} \pm 21.6$ & $3.17^{\mathrm{a}} \pm 8.6$ \\
Tofu A & $9.6^{\mathrm{b}} \pm 3.6$ & $0.22^{\mathrm{b}} \pm 0.6$ \\
Soybean B in grains & $148,4^{\mathrm{c}} \pm 21.6$ & $1.56^{\mathrm{c}} \pm 8.6$ \\
Tofu B & $18.3^{\mathrm{d}} \pm 3.6$ & $0.15^{\mathrm{d}} \pm 0.6$
\end{tabular}

Results are expressed as mean \pm standard deviation $(n=3)$. Averages in the same column with different letters are significantly different $(\mathrm{p}<0.05)$. ${ }^{*}$ equivalent $\mathrm{mg}$ of gallic acid/100g of sample; $* * \mu \mathrm{mol}$ of ferrous sulfate $/ \mathrm{g}$ of sample.

In this study, soybean grains showed more antioxidant activity (AA) and phenolic compounds than soybeans processed as tofu. According to Wang and Murphy (1996), the presence and concentration of isoflavonoids in soy-based products depend upon the processing conditions.

The FRAP method allowed us to verify that the AA values of soya were 1.56 and $3.17 \mu \mathrm{mol}$ of ferrous sulfate/g of sample. Thus, antioxidant activity of brand A soya appeared above that of brand B, with a $5 \%$ greater probability by Tukey's test. In processed products such as tofu, AA tends to be $50 \%$ lower than in raw soybeans, indicating some soybean processing methods affect antioxidant capacity (LEE et al., 2004). The results in table 2 represent decreases much higher than $50 \%$ for AA. 
The free radical scavenging method (DPPH) found no significant difference $(\mathrm{P}>0.05)$ between different tofu and soybean brands or their derivatives. Hence, we expressed the results as the ability to capture or decrease the DPPH percentage and the $\mathrm{IC}_{50}$ value, a parameter indicative of the inhibitory concentration necessary to halve the free radical DPPH $\left(\mathrm{IC}_{50}\right)$. The $\mathrm{IC}_{50}$ values for soybean brands $\mathrm{A}$ and $\mathrm{B}$ were 3.12 and $3.13 \mathrm{mg} / \mathrm{mL}$, and for tofu brands $\mathrm{A}$ and $\mathrm{B}, 3.23$ and $3.24 \mathrm{mg} / \mathrm{mL}$.

Soybean and tofu extracts of both brands showed antioxidant activity at all concentrations, with inhibition greater than $50 \%\left(\mathrm{IC}_{50}\right)$. The tofu samples were less active, and $\mathrm{AA}$ was significantly higher in the most concentrated extracts (Figure 2).

\section{DPPH Radical Scavenging Activity}

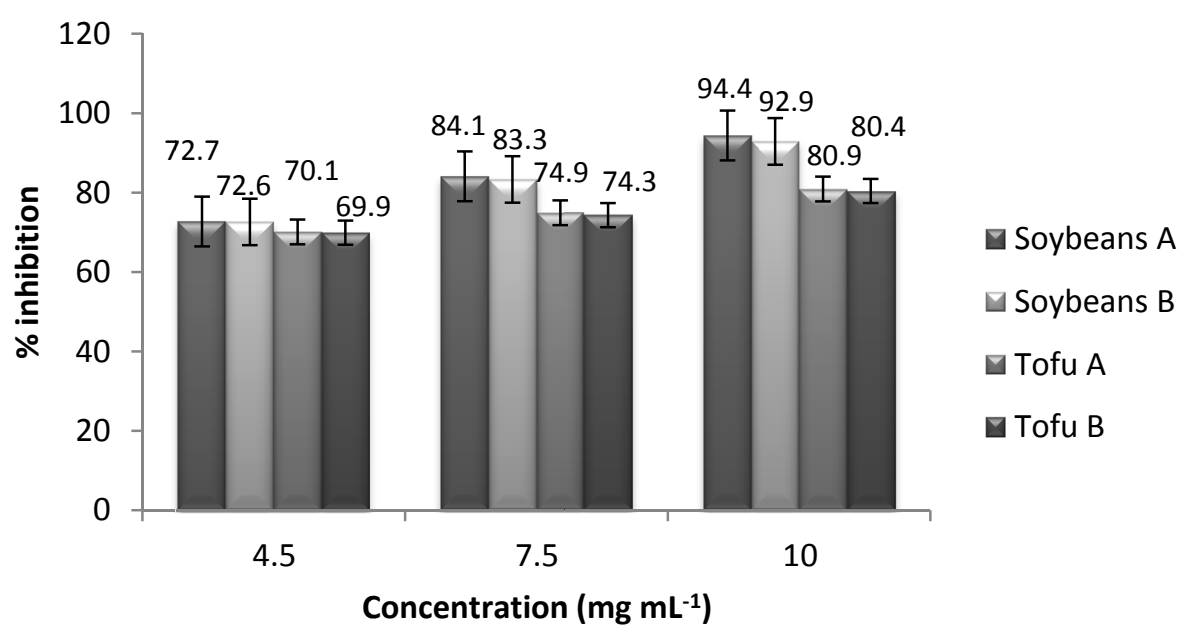

Figure 2. DPPH radical scavenging inhibition

\section{Conclusion}

According to this study, soybeans have a good antioxidant activity. The antioxidant activity of tofu was less expressive. Yet, it could pose as an alternative antioxidant source, since soybean consumption is limited in Brazil.

The soybean brands showed important differences $(\mathrm{P}<0.05)$ in reducing capacity of Folin-Ciocalteu reagent and iron reduction power (FRAP). The inhibition of DPPH radicals, in turn, substantially increased as sample concentrations increased.

Both soybean grains and tofu showed a lipid profile primarily made up of unsaturated fatty acids essential for the human diet.

\section{Acknowledgements}

The authors thank the CNPq and CAPES for the financial support.

\section{References}

Axelrod, B., Cheesebrough, T. M., \& Laaksso, S. (1981). Lipoxygenase from soybeans. Methods in Enzymology, $71,441-451$.

Bannon, C. D., Breen, G. J., Craske, J. D., Hai, N. T., Harper, N. L., \& O’Rourke, K. L. (1982). Analysis of fatty acid methyl esters with high accuracy and reliability. 3. Literature-review of and investigations into the development of rapid procedures for the methoxide-catalyzed methanolysis of fats and oils. Journal of Chromatography, 247, 71-89. http://dx.doi.org/10.1016/S0021-9673(00)84857-8

Bayram, M., Kaya, A., \& Oner, M. D. (2004). Changes in properties of soaking water during production of soy-bulgur. Journal of Food Engineering, 61, 221-230. http://dx.doi.org/10.1016/S0260-8774(03)00094-3 
Benassi, V. T., Benassi, M. D. T., \& Prudencio, S. H. (2011). Brazilian soybean cultivars: tofu-making characteristics and acceptance by consuming market. Semina-Ciencias Agrárias, 32, 1901-1914. http://dx.doi.org/10.5433/1679-0359.2011v32Suplp1901

Benzie, I. F. F., \& Strain, J. J. (1996). The ferric reducing ability of plasma (FRAP) as a measure of "antioxidant power:” The FRAP assay. Analytical Biochemistry, 239, 70-76. http://dx.doi.org/10.1006/abio.1996.0292

Bligh, E. G., \& Dyer, W. J. (1959). A rapid method of total extraction and purification. Canadian Journal of Biochemestry and Physiology, 37, 911-917.

Brand-Williams, W., Cuvelier, M. E., \& Berset, C. (1995). Use of a free radical method to evaluate antioxidant activity. Food Science And Technology-Lebensmittel-Wissenschaft \& Technologie, 28, 25-30.

BRASIL. Agência Nacional da Vigilância Sanitária - ANVISA. RDC \#482, de 23/09/1999. Retrieved from http://e-legis.bvs.br/leiref/pu

Crouse, J. R., Morgan, T., Terry, J. G., Ellis, J., Vitolins, M., \& Burke, G. L. (1999). A randomized trial comparing the effect of casein with that of soy protein containing varying amounts of isoflavones on plasma concentration of lipids and lipoproteins. Archives of Internal Medicine, 159, 2070-2076. http://dx.doi.org/10.1001/archinte.159.17.2070

Davies, C. S., \& Nielsen, N. C. (1986). Genetic analysis of a null-allele for lipoxygenase-2 in soybeans. Crop Science, 26, 460-463.

Escueta, E. E., Bourne, M. C., \& Hood, L. F. (1986). Effect of boiling treatment of soymilk on the composition yield texture and sensory properties of tofu. Canadian Institute of Food Science and Technology Journal, 19, 53-56.

FAO (Food and Agriculture Organization of the United Nation). (2007). Organização das Nações Unidas para Agricultura e Alimentação. Retrieved Feb 15, 2013, from http://faostat.fao.org/site/601/defaut.aspx

Lee, J., Renita, M., Fioritto, R. J., St. Martin, S. K., Schwartz, S. J., \& Vodovotz, Y. (2004). Isoflavone characterization and antioxidant of Ohio soybeans. Journal of Agricultural and Food Chemistry, 52, $2647-2651$. http://dx.doi.org/10.1021/jf049108e

Loss, A., Pereira, M. G., Perin, A., \& Anjos, L. H. C. (2012). Carbon and Nitrogen Content and Stock in No-Tillage and Crop-livestock Integration Systems in the Cerrado of Goias State, Brazil. Journal of Agricultural Science, 4, 96-105. http://dx.doi.org/10.5539/jas.v4n8p96

Neves, J. A., Silva, J. A. L., Barbosa, D. R. S., Sedyama, T., Teixeira, R. C., \& Rocha, R. S. (2013). Agronomic Performance of Soybean Genotypes in Low Latitude in Teresina-PI, Brazil. Journal of Agricultural Science, 5, 243-253. http://dx.doi.org/10.5539/jas.v5n3p243

Rackis, J. J., Sessa, D. J., \& Honig, D. H. (1979). Flavor problems of vegetable food proteins. Journal of the American Oil Chemists' Society, 56, 262-271. http://dx.doi.org/10.1007/BF02671470

Rockland, L. B., \& Radké, T. M. (1981). Legume protein quality. Food Technology-Chicago, 35, 79-82.

Sánchez-Moreno, C., Larrauri, J. A., \& Saura-Calixto, F. (1998). A procedure to measure the antiradical efficiency of polyphenols. Journal of the Science of Food and Agriculture, 76, 270-276. http://dx.doi.org/10.1002/(SICI)1097-0010(199802)76:2<270::AID-JSFA945>3.0.CO;2-9

Shan, B., Cai, Y. Z., Sun, M., \& Corke, H. (2005). Antioxidant capacity of 26 spice extracts and characterization of their phenolic constituents. Journal of Agricultural and Food Chemistry, 53, 7749-7759. http://dx.doi.org/10.1021/jf051513y

Simionato, J. I., Garcia, J. C, dos Santos, G., T., Oliveira, C. C., Visentainer, J. V., \& de Souza, N. E. (2010). Validation of the Determination of Fatty Acids in Milk by Gas Chromatography. Journal of the Brazilian Chemical Society, 21, 520-524. http://dx.doi.org/10.1590/S0103-50532010000300018

Statistica 7.0 Software. (2005). Statsoft Inc., Tucksa, USA.

Swain, T., \& Hillis, W. E. (1959). The Phenolic Constituents of Prunus Domestica. The Quantitative analysis of Phenolic constituents. Journal of the Science of Food and Agriculture, 10, 63-68.

Tsai, S. J., Lan, C. Y., Kao, C. S., \& Chen, S. C. (1981). Studies on the yield and quality characteristics of tofu. Journal of Food Science, 46, 1734. http://dx.doi.org/10.1111/j.1365-2621.1981.tb04474.x 
Van Hung, P., Maeda, T., Miyatake, K., \& Morita, N. (2009). Total phenolic compounds and antioxidant capacity of wheat graded flours by polishing method. Food Research International, 42, 185-190. http://dx.doi.org/10.1016/j.foodres.2008.10.005

Wang, H., \& Murphy, P. A. (1996). Mass balance study of isoflavones during soybean processing. Journal of Agricultural and Food Chemistry, 44, 2377-2383. http://dx.doi.org/10.1021/jf950535p

Wang, Y. C., Yu, R. C., \& Chou, C. C. (2006). Antioxidative activities of soymilk fermented with lactic acid bacteria and bifidobacteria. Food Microbiology, 23, 128-135. http://dx.doi.org/10.1016/j.fm.2005.01.020

Wettasinghe, M., \& Shahidi, F. (1999). Evening Primrose Meal: A Source of Natural Antioxidants and Scavenger of Hydrogen Peroxide and Oxygen-Derived Free Radicals. Journal of Agricultural and Food Chemistry, 47, 1801-1812. http://dx.doi.org/10.1021/jf9810416

Wood, J. D., Richardson, G. R., \& Fisher, A. V. (2003). Effects of fatty acids on meat quality: A review. Meat Science, 66, 21-32. http://dx.doi.org/10.1016/S0309-1740(03)00022-6

Yehuda, S., Rabinovitz, S., Carasso, R. L., \& Mostofsky, D. I. (2002). The role of polyunsaturated fatty acids in restoring the aging neuronal membrane. Neurobiology of Aging, 23, 843-53. http://dx.doi.org/10.1016/S0197-4580(02)00074-X

Youdim, K. A., Martin, A., \& Joseph, J. A. (2000). Essential fatty acids and the brain: possible health implications. International Journal of Developmental Neuroscience, $18, \quad 383-99$. http://dx.doi.org/10.1016/S0736-5748(00)00013-7

\section{Copyrights}

Copyright for this article is retained by the author(s), with first publication rights granted to the journal.

This is an open-access article distributed under the terms and conditions of the Creative Commons Attribution license (http://creativecommons.org/licenses/by/3.0/). 